\title{
DESCRIPTIONS OF FOUR NEW SPECIES OF EUSTICTUS
} (HEMIPTERA, MIRIDÆ). ${ }^{1}$

\author{
By Harry H. KNight, \\ Ames, Iowa.
}

\section{Eustictus ainsliei n. sp.}

This species runs to venatorius Van. D., in my key to the species (Hem. Conn., 1923, p. 481), but is distinguished by the long hairs on antennal segment I, by the shorter length of segment $I$ as compared with width of head, by the long bristle-like hairs on pronotum, and long hairs on hind femora instead of spines.

$0^{7}$. Length $6.4 \mathrm{~mm}$., width $2.4 \mathrm{~mm}$. Head: width 1.32 $\mathrm{mm}$., vertex $.23 \mathrm{~mm}$. Rostrum, length $3 \mathrm{~mm}$., extending upon fourth ventral segment. Antennæ: segment I, length $.98 \mathrm{~mm}$., thickness $.17 \mathrm{~mm}$., set with erect bristle-like hairs, length of several hairs greater than diameter of segment, mottled with black and white; II, $2.7 \mathrm{~mm}$., brownish black with a few fine pale marks evident; III, $1.4 \mathrm{~mm}$., with more pale than segment II; IV, $1.35 \mathrm{~mm}$., brownish black. Pronotum: length 1.23 $\mathrm{mm}$., width at base $2.14 \mathrm{~mm}$.

Coloration very suggestive of venatorius, but more broadly white on hemelytra, basal half of pronotum, and front of head; calli black, with five blackish rays extending back half way to basal margin. Dorsum clothed with erect long hairs, distinctly bristle-like on pronotum; apical half of femora and basal half of hind tibiæ set with long erect hairs, the hind femora without true spines such as are found in venatorius.

Holotype: $\sigma^{7}$ April 14, Orlando, Florida (G. G. Ainslie), collected at light; author's collection. Named after the collector, Mr. G. G. Ainslie who kindly presented the specimen.

\footnotetext{
${ }^{1}$ Contribution from the Department of Zoology and Entomolozy, Iowa State College, Ames, Iowa.
} 


\section{Eustictus spinipes n. sp.}

Allies to mundus Uhler, but distinguished by the longer antennal segment I and the strong spines on apical half of femora and basal half of hind tibiæ.

$\sigma^{7}$. Length $4.9 \mathrm{~mm}$., width $1.8 \mathrm{~mm}$. Head: width 1.01 $\mathrm{mm}$., vertex $.36 \mathrm{~mm}$.; eyes smaller and vertex much wider than in mundus. Rostrum, length $2.46 \mathrm{~mm}$., attaining base of fourth ventral segment. Antennæ: segment I, length $.81 \mathrm{~mm}$., thickness $.157 \mathrm{~mm}$., set with short bristle-like hairs which in length do not exceed half the width of segment; II, $2.2 \mathrm{~mm}$.; III, 1.14 $\mathrm{mm}$; IV, .94 mm.; all the segments red without dark markings, last segment somewhat darker red. Pronotum: length 1.06 $\mathrm{mm}$., width at base $1.67 \mathrm{~mm}$.

Coloration very similar to mundus but with antennæ reddish. Hind femora with several long spines on apical half, occurring on dorsal surface near apex only; hind tibiæ set with regular rows of strong spines, longer on basal half, length exceeding thickness of tibia.

Holotype: ơ August 25, 1925, Sanford, Florida (E. D. Ball); author's collection.

\section{Eustictus pilipes n. sp.}

Coloration nearly as in spinipes, but differs in the long, erect hairs on first antennal segment and the longer, erect hairs on tibiæ and femora.

․ Length $5.9 \mathrm{~mm}$., width $2.2 \mathrm{~mm}$. Head: width 1.13 mm., vertex $.46 \mathrm{~mm}$. Rostrum, length $2.93 \mathrm{~mm}$., extending upon fifth ventral segment. Antennæ: segment I, length .97 $\mathrm{mm}$., thickness $.18 \mathrm{~mm}$., bearing erect bristle-like hairs, several of which exceed thickness of segment; II, $2.77 \mathrm{~mm}$.; III, 1.42 mm.; IV, $1.14 \mathrm{~mm}$; red, without black marks. Pronotum: length $1.13 \mathrm{~mm}$., width at base $1.89 \mathrm{~mm}$.

Coloration nearly as in spinipes, but head, antennæ, and legs of deeper red. Spines on basal half of hind tibiæ replaced by long hairs several of which in length are equal to three times thickness of tibia. Femora also bearing long hairs on ventral margin, and apically on posterior and dorsal margins. 
Holotype: $ᄋ$ August 30, 1925, Sanford, Florida (E. D. Ball); author's collection. Paratypes: 2 \% July 18, 1894, Tavures, Florida.

The coloration of this species would suggest that it might be the female of spinipes, but of twelve species known from both sexes, no variation of tibial spines and hairs, and type of hairs on antennæ occurs.

\section{Eustictus pubescens n. sp.}

Distinguished by the short but rather abundant pubescence on legs, body and antennæ; legs and antennæ uniformly yellowish without black marks.

오 Length $5.7 \mathrm{~mm}$., width $2.74 \mathrm{~mm}$. Head: width 1.2 $\mathrm{mm}$., vertex $.40 \mathrm{~mm}$. Rostrum, length $2.29 \mathrm{~mm}$., scarcely attaining posterior margins of intermediate coxæ. Antennæ: segment I, length $.68 \mathrm{~mm}$., thickness $.18 \mathrm{~mm}$., clothed with very short stiff pale hairs; II, $1.7 \mathrm{~mm}$., somewhat more slender at base; III, .97 mm.; IV, $1.11 \mathrm{~mm}$.; uniformly yellowish. Pronotum: length $1.21 \mathrm{~mm}$., width at base $2.3 \mathrm{~mm}$.; rather sparsely and coarsely punctate; scutellum smooth.

Coloration rather uniformly yellowish, pronotal disk and scutellum fuscous, calli paler. Embolium broad and flat, clear, yellowish to red on apex, embolar margins thickly set with short pubescence. Membrane, inner and apical angles of cuneus, fuscous. Legs thickly clothed with erect, short pale pubescent hairs, tibial spines very short and confused with the hairs.

Holotype: ㅇ․ June 11, 1913, Monticello, Florida (H. B. Scammell); Cornell University collection. 

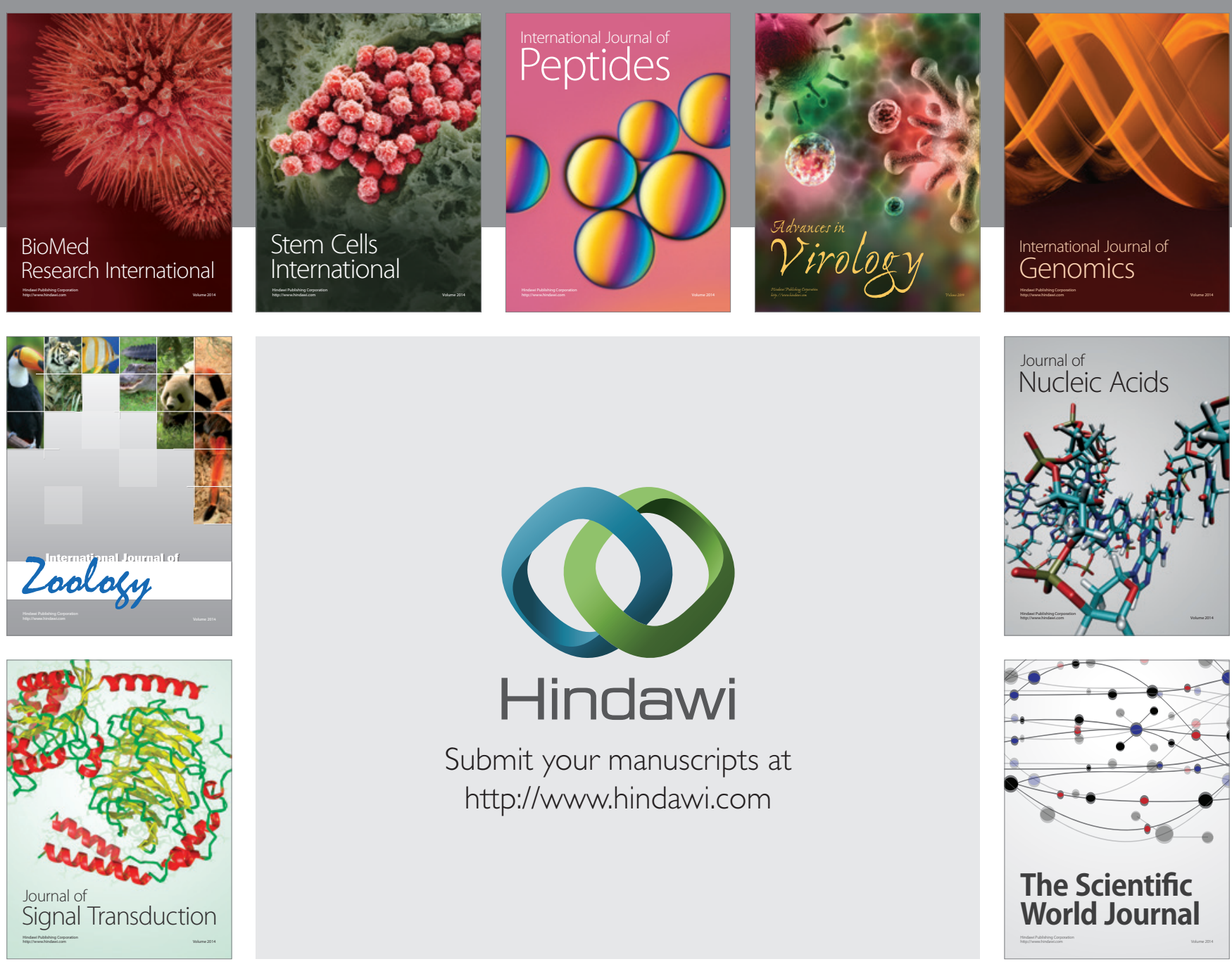

Submit your manuscripts at

http://www.hindawi.com
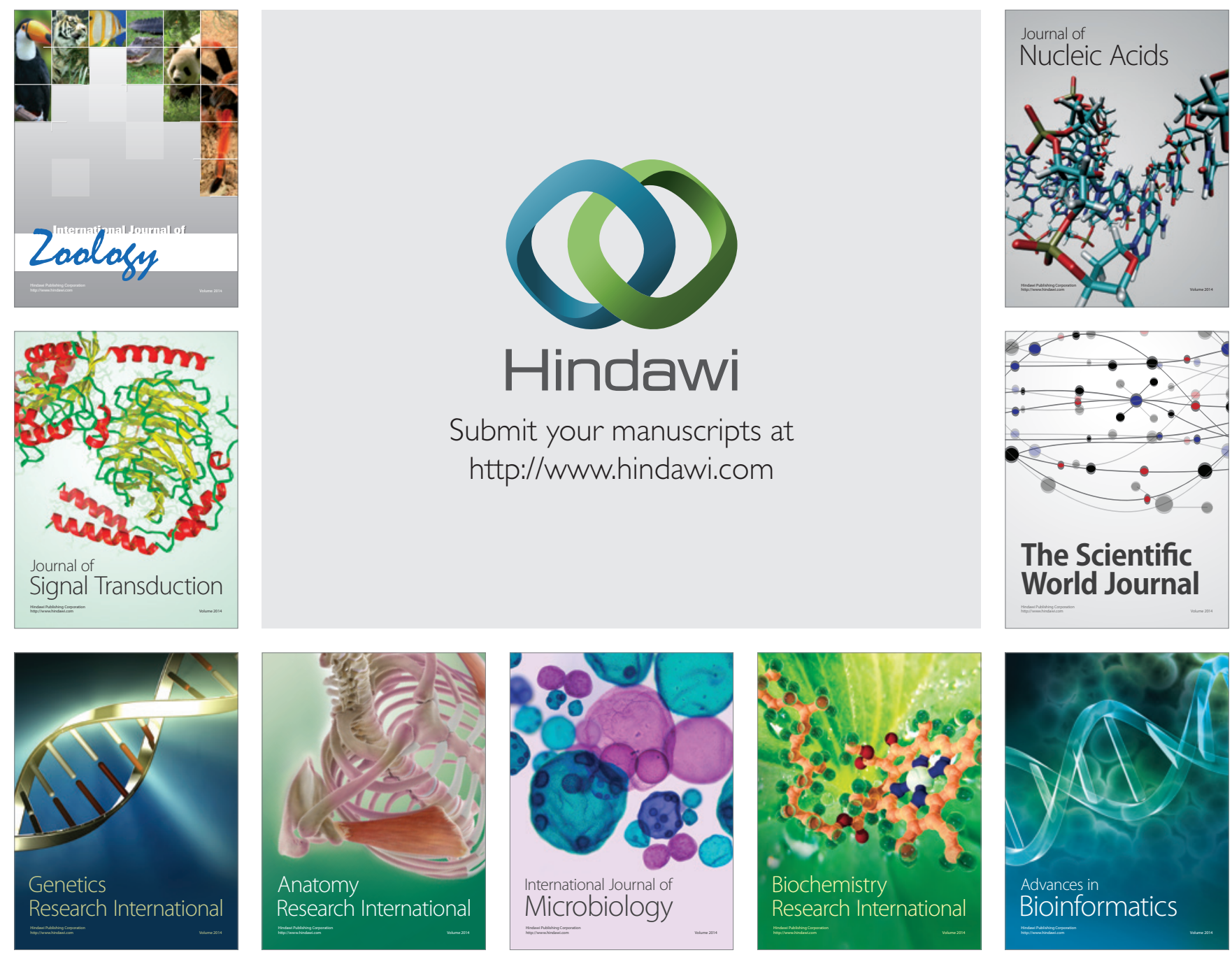

The Scientific World Journal
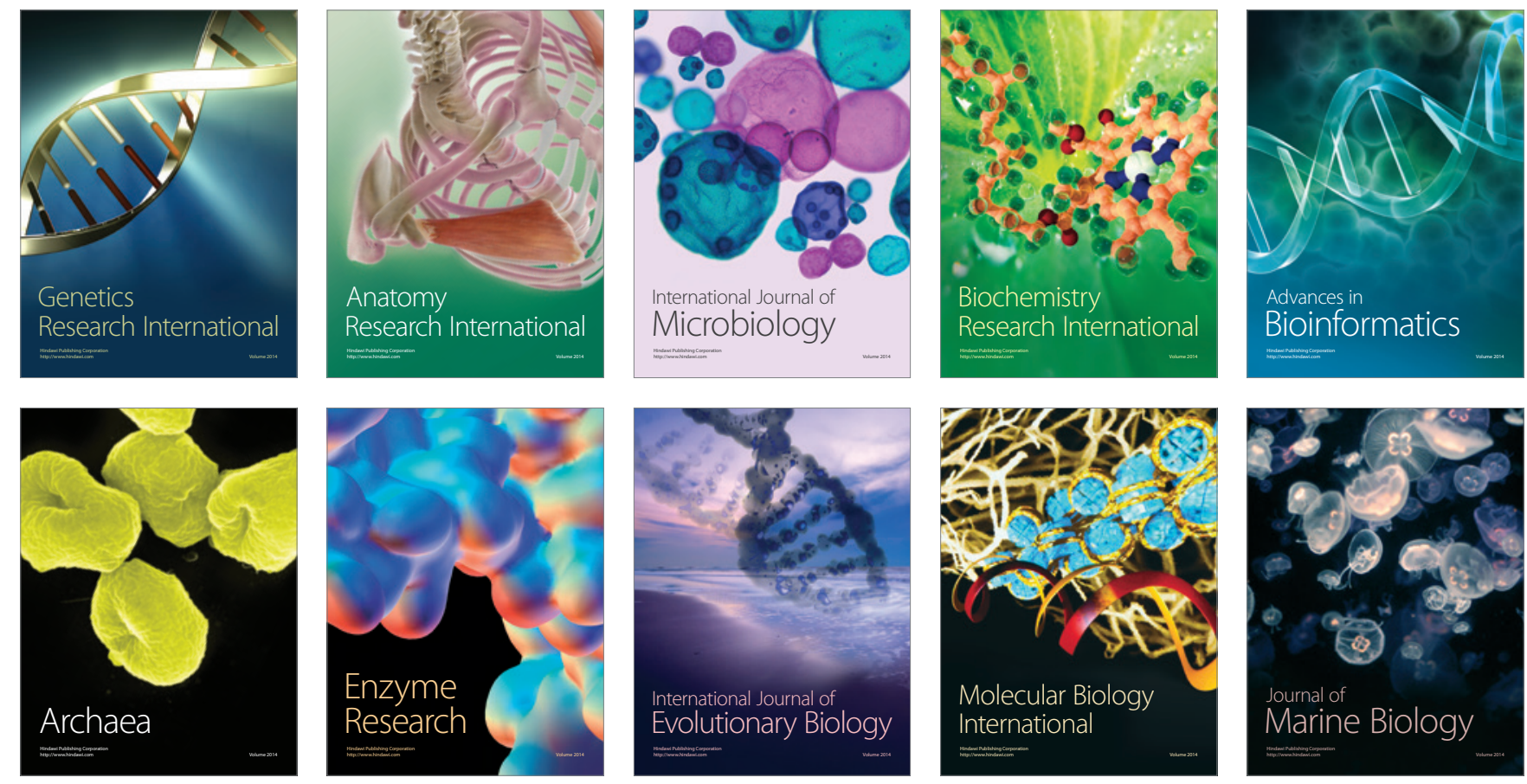